\title{
Diet of the Fuscous Flycatcher Cnemotriccus fuscatus (Wied, 1831) - Aves, Tyrannidae - in three habitats of the northern Pantanal, Mato Grosso, Brazil
}

\author{
Gaiotti, $M G^{*}{ }^{*}$ and Pinho, JB. \\ Laboratório de Ornitologia, Universidade Federal de Mato Grosso, Instituto de Biociências, \\ Av. Fernando Corrêa da Costa, s/n, Coxipó, CEP: 78060-900, Cuiabá, Mato Grosso, Brazil \\ *e-mail: enelim@gmail.com \\ Received July 16, 2012 - Accepted October 9, 2012 - Distributed November 29, 2013
}

(With 2 figures)

\begin{abstract}
The Fuscous Flycatcher (Cnemotriccus fuscatus) is a medium-sized Tyrannidae widespread in South America. Despite its large distribution, there have been very few studies on its diet, especially in different habitats. This study presents data on diet variation in three habitats in the Pantanal wetlands in the state of Mato Grosso, Brazil. The specimens were captured through a mist-netting programme between February 2000 and May 2010, in the Retiro Novo Farm, in the Poconé municipality. Birds were captured in three vegetation types: Landizal, Cambarazal and Cordilheira. Tartar emetic was used to obtain the regurgitation samples identified at order level. We captured 61 individuals (21, 26 and 14 in the above described habitats, respectively). Diet of $C$. fuscatus differed between the three habitats. Ants and beetles were the most relevant prey items either in numerical frequency (NF) or in frequency of occurrence (OF), in terms of the overall diet $(\mathrm{NF}=27.34 \%$ and $37.89 \% ; \mathrm{OF}=36.06 \%$ and $75.4 \%$, respectively $)$. However, in Cordilheira, seeds and beetles dominated the NF ( $21.8 \%$ and $38.1 \%$, respectively) and OF (28.5\% and $85.7 \%$, respectively). Cnemotriccus fuscatus was found to have an omnivorous diet, although in Cambarazal, individuals preyed exclusively on arthropods. The present study provides an important contribution to the knowledge of the diet of a poorly studied Neotropical bird.
\end{abstract}

Keywords: diet, Fuscous Flycatcher, Pantanal, tartar emetic.

\section{Dieta de Cnemotriccus fuscatus (Wied, 1831) - Aves, Tyrannidae - em três habitats do Pantanal norte, Mato Grosso, Brasil}

\section{Resumo}

O Guaracavuçu (Cnemotriccus fuscatus) é um tyranídeo de tamanho médio, bem distribuído na América do Sul. Apesar de sua ampla distribuição, existem poucos estudos sobre a sua dieta, especialmente em diferentes habitats. Este estudo apresenta dados sobre a variação da dieta de C. fuscatus, em três diferentes fitofisionomias do Pantanal norte, Mato Grosso, Brasil. As aves foram capturadas em redes de neblina entre fevereiro de 2000 e maio de 2010, na fazenda Retiro Novo no município de Poconé. Os espécimes foram amostradas em três diferentes tipos de vegetação: Cambarazal, Landizal e Cordilheira. O tartarato emético foi usado para obtenção das amostras de regurgito que foram identificadas ao menor nível taxonômico possível. Foram capturados 61 indivíduos (26, 21 e 14 indivíduos nos habitats descritos acima, respectivamente). A dieta de C. fuscatus foi diferente entre as três fitofisionomias. Em geral, Formicidae e Coleoptera foram os itens alimentares mais relevantes tanto nas frequências numérica (FN) (FN 27,34\% e 37,89\%, respectivamente) quanto na frequência de ocorrência (FO) (FO $=36,06 \%$ e 75,4\%, respectivamente). Entretanto, na Cordilheira as sementes (ou frutos) e os Coleoptera dominaram a FN $(21,8 \%$ e $38,1 \%$, respectivamente) e a FO (28,5\% e 85,7\%, respectivamente). Cnemotriccus fuscatus apresentou uma dieta onívora, porém no Cambarazal a espécie consumiu apenas artrópodes. O presente estudo fornece uma importante contribuição para o conhecimento da dieta de uma ave Neotropical tão pouco estudada.

Palavras-chave: dieta, Guaracavuçu, Pantanal, tartarato emético.

\section{Introduction}

Diet has been considered one of the greatest influences on a bird's life, affecting both the fecundity and survival of adults (Charnov and Krebs, 1974; Murphy and Haukioja, 1986; Nur, 1990) and providing relevant information on conservation issues. However, much information is still missing and habitat degradation continues to occur (Harris et al., 2005; Alho, 2008). Intense 
human occupation in the Pantanal, the largest wetland in central Brazil (Alho, 2008), has contributed to biodiversity loss, particularly through the degradation and fragmentation of habitats (Costa, 1999; Padovani et al., 2004; Alho, 2008;).

Seasonal variation in resource availability is very conspicuous in the Brazilian Pantanal due to flooding cycles, which leads the birds to move across different habitats to search for specific food resources (Nunes da $\mathrm{Cu}-$ nha and Junk, 2009; Yabe et al., 2010;). Resident passerines, in general, have difficulty in flying long distances, so the use of resources that are available throughout the year (e.g. arthropods) or a generalist diet is essential to their permanence in a given habitat (Stouffer and Bierregaard, 1995).

The Fuscous Flycatcher Cnemotriccus fuscatus (Wied, 1831) is a medium-sized Tyrannidae largely widespread in South America. It is commonly found in the understory of gallery and secondary woodlands, forest borders and ranges from river islands in Colombia and Venezuela to northern Argentina (Ridgley and Tudor, 2009). Despite its large distribution, very few studies have been published about this species, most of all related to geographic distribution (Piacentini et al., 2006; Vasconcelos and D'Angelo Neto, 2007; Pinheiro and Dornas, 2009) and photographic records (Guedes, 2012). The species has been classified as an insectivorous bird (Durães and Marini, 2005; Lopes et al., 2005), having a known seasonal variation in its diet, insects prevailing (Souto, 2010). In the Brazilian Pantanal, the Fuscous Flycatcher is known to occur in almost all habitat types ( $\mathrm{Si}$ gnor and Pinho, 2011). For this reason, it is an ideal model to study diet variations between different types of vegetation. Thus the aim of this study is to test if $C$. fuscatus presents a variation in its diet between different vegetation types.

\section{Material and Methods}

The birds were captured with 10 mist-nets $(36 \mathrm{~mm}$ and 12x3 m) between February 2000 and May 2010, on the Retiro Novo Farm, Poconé municipality, Mato Grosso, Brazil (16 $16^{\prime} 12^{\prime \prime} \mathrm{S}$ and $\left.56^{\circ} 22^{\prime} 12^{\prime \prime} \mathrm{W}\right)$. Mist nets were open from $6 \mathrm{~h}$ to $11 \mathrm{~h}$. All captured individuals were identified according to the Comitê Brasileiro de Registros Ornitológicos (CBRO, 2009) and ringed following the Centro de Estudos para Conservação das Aves Silvestres (CEMAVE, 1994). Three different vegetation types were sampled, locally known as Cambarazal, Cordilheira and Landizal, and three replicas of each were used. Any two sites were separated by at least $250 \mathrm{~m}$ of grassland and any two sites of the same vegetation type were at least $800 \mathrm{~m}$ apart to ensure sampling independence (see Figure 1; Pinho and Marini [2011] for details). The habitat types were classified as described by Nascimento and Nunes da Cunha (1989) and Nunes da Cunha and Junck (2001, 2009):

1- Cambarazal: monodominant forest formations of Vochysia divergens (Spohl) which are seasonally

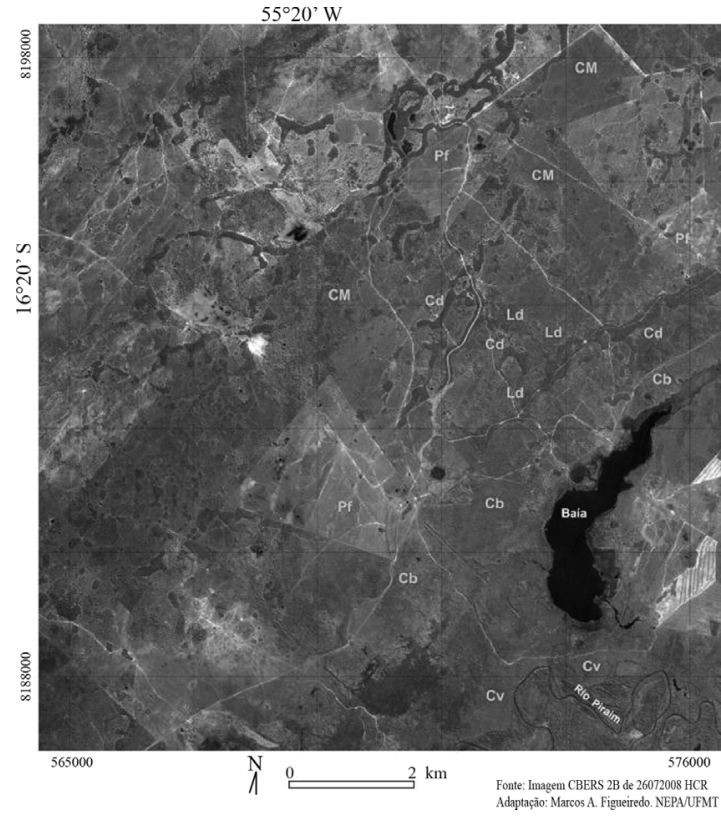

Figure 1 - Replica location of the three vegetation types studied: Cambarazal $(\mathrm{Cb})$, Cordilheiras $(\mathrm{Cd})$ and Landizal (Ld), from the Pirizal region, in the northern Pantanal, Mato Grosso, Brazil. CM and Pf are non-studied environments, which represents grasslands.

flooded, with high and homogeneous canopy. This vegetation type is known to be invasive of flooded grassland.

2- Landizal: semi-deciduous vegetation dominated by Calophyllum brasiliensis (Cambess) with seasonal flooding and shallow depressions.

3- Cordilheira: tight and continuous semi-deciduous vegetation, considered to be an "always dry" forest because this type almost never floods.

The regurgitation method, with tartar emetic (1\%) in a dosage of $1 \mathrm{~mL}$ to $100 \mathrm{~g}$ body weight, was performed to obtain dietary data (Poulin and Lefebvre, 1995; Durães and Marini, 2003). Due to risks associate to tartar emetic method application some cautions were taken as none individual with less than $5 \mathrm{~g}$ of mass was submitted to method and the individuals stay in a box (for regurgitation) only for $30 \mathrm{~min}$ (with or without regurgitation). None $C$. fuscatus died during the method (whereas all flew after release) and 11 individuals were recaptured after received the tartar emetic. The prey items were analysed and identified at order level. Only complete seeds were counted to avoid an overestimate. The occurrence frequency (OC) and numerical frequency (NF) were calculated for each individual food item in each vegetation type, in order to find out what was the most important food item in the diet was.

The Chi-squared test was performed with PAST software (Hammer et al., 2001) to evaluate the differences in the diet of $C$. fuscatus among the three analysed vegetation types. Significance level were considered as $\mathrm{p}<0.05$. Similarity diet between vegetation types was 
calculated using the Jaccard $\left(S J_{i j}\right)$ similarity index. To calculate niche width, we used the method described by Pielou (1975) and applied to the data of stomach contents by Hurtubia (1973). Both authors estimate the diversity of items consumed by a bird population, assuming that this index represents the dietary niche width (Sherry 1984). Thus, dietary niche width was calculated using the Brillouin diversity index $(\mathrm{H})$. This index was used for assume the non-randomisation of the data, since each stomach containing a set of preys potentially nonrandom (Pielou, 1975), and take into account the sampling of the entire community (i.e. the stomach of each individual), and also consider both richness and the evenness (Pielou 1975).

\section{Results}

A total of 61 individuals were captured, 26 in Cambarazal, 21 in Landizal and 14 in Cordilheira. No individual ringed in a vegetation type was captured in the others, neither between replicas. A total of 20 different prey items were consumed by $C$. fuscatus. Ants and beetles were the most important prey items in terms of NF and OF for the overall diet $(\mathrm{NF}=27.34 \%$ and $37.89 \%$; $\mathrm{OF}=36.06 \%$ and $\mathrm{OF}=75.4 \%$, respectively) and in 2 habitats types (see Figure 2): Cambarazal $(\mathrm{NF}=45.9 \%$ and $32.4 \%$; $\mathrm{OF}=38.46 \%$ and $61.53 \%$, respectively) and Landizal $(\mathrm{NF}=11.1 \%$ and $44.4 \%$; $\mathrm{OF}=33.3 \%$ and $85.7 \%$, respectively). However, although beetles dominated, in Cordilheira the frequency of food items was more evenly distributed $(\mathrm{NF}=38.1 \%$ and $\mathrm{OF}=85.7 \%)$. Formicidae, Orthoptera and Hymnoptera exhibit an OF of $35.7 \%(\mathrm{NF}=16.3 \%, 9.09 \%$ and $9.09 \%$, respectively) and the seeds (represented by Cereus sp. and E. deciduum) together exhibit an NF of $21.8 \%$ and an OF of $28.5 \%$ (see Figure 2).

The diet of Fuscous Flycatcher differed between the three vegetation types (Cambarazal/Cordilheira: $\mathrm{X}_{14}^{2}=45.1, \mathrm{p}<0.001$; Cambarazal/Landizal: $\mathrm{X}_{17}^{2}=63.1$, $\mathrm{p}<0.001$; Cordilheira/Landizal: $\mathrm{X}_{15}^{2}=42.5, \mathrm{p}<0.001$ ), having preyed exclusively on arthropods in Cambarazal. The $C$. fuscatus dietary niche was larger in Landizal (0.713) followed by Cordilheira (0.689) and Cambarazal (0.59). Diet similarity was higher between Cambarazal/Landizal $\left(S J_{i j}=0.44\right)$, followed by Landizal/Cordilheira $\left(S J_{i j}=0.43\right)$ and Cambarazal/Cordilheira $\left(S J_{i j}=0.40\right)$.

\section{Discussion}

Variation on proportions of food items shown by the Fuscous Flycatcher among vegetation types could be explained by several factors such as availability or abundance of environments resources (Poulin et al., 1992; Poulin et al., 1994). This could indicate opportunism in C. fuscatus in terms of food exploitation (Poulin et al., 1994). However availability and viability of food data should be collected to confirm this.

Since the bird species composition is different between the vegetation types (Pinho and Marini, 2011), the

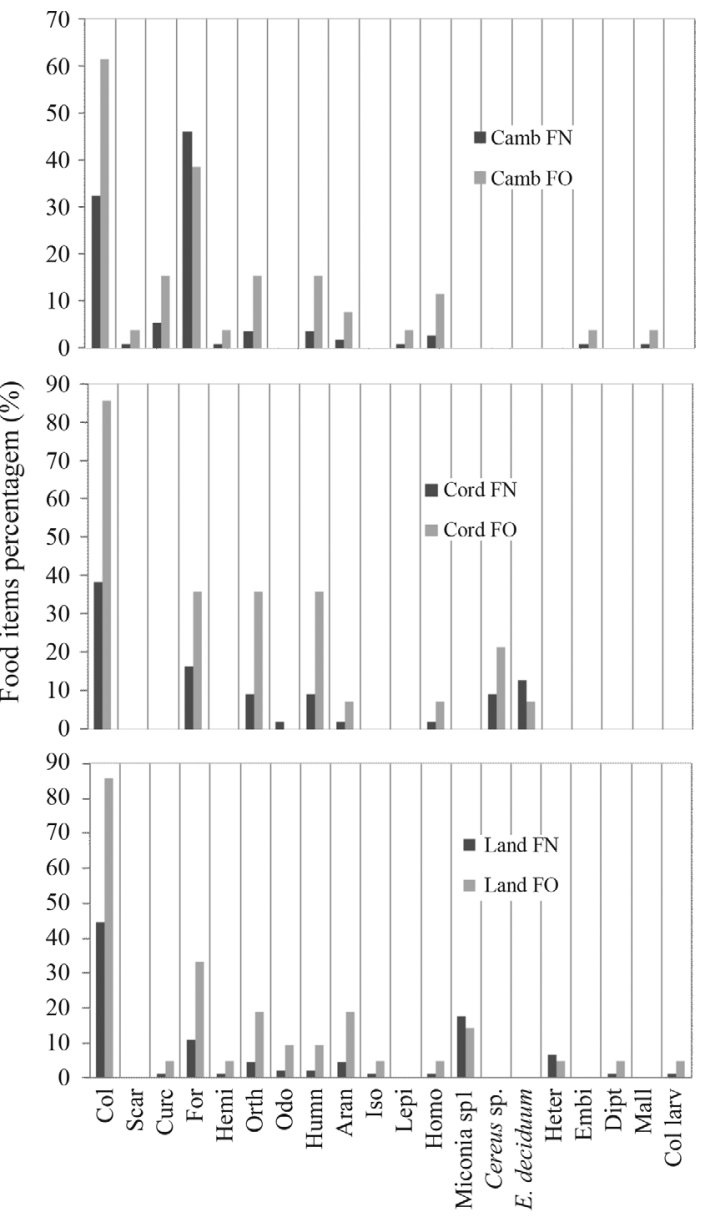

Food items in C. fuscatus diet

Figure 2 - Food items displayed by numerical frequency and occurrence frequency (FN and $\mathrm{FO}$, respectively) found in the diet of $C$. fuscatus in the three vegetation types studied: Cambarazal (Camb), Cordilheira (Cord) and Landizal (Land). Col: Coleoptera, Scar: Scarabaeidae. Curc: Curculionoidae, For: Formicidae, Hemi: Hemiptera, Orth: Orthoptera, Odo: Odonata, Hymn: Hymenoptera, Aran: Aranae, Iso: Isoptera, Lepi: Lepidoptera, Homo: Homoptera, Heter: Heteroptera, Embi: Embioptera, Dipt: Diptera, Mall: Mallophaga, Col. Larv.: Coleoptera larvae.

competition effect, which is also probably different, could affect the diet (Rotenberry, 1980). Therefore, in one vegetation type, C. fuscatus may compete for a determinate resource, whereas in another vegetation type, this competition could not occur (MacArthur and Levins, 1967; Beaver and Baldwin, 1975). Although others factors could influence its diet such as temporal variation and different abundance in resource (Poulin et al., 1992), as in the case of Formicidae and Coleoptera that were more abundant than others arthropods in Cambarazal (Ferreira et al., 2001; Marques et al., 2010).

In this way the higher fruit consumption (Cereus sp. and $E$. deciduum) by individuals in Cordilheira than the individuals of the other vegetation types could be ex- 
plained by the greatest fruit availability, particularly cactus fruits such as Cereus sp., in this environment than in the others (Nunes da Cunha and Junk, 2009).

The broad dietary niche width suggests that $C$. fuscatus has the capacity to eat many types of food items, including seeds and fruit, allowing greater niche plasticity (Colwell and Futuyma, 1971). Despite many studies describing this species as exclusively insectivorous (Durães and Marini, 2005; Lopes et al., 2005; Souto, 2010), the results of the present study demonstrate that $C$. fuscatus have an omnivorous diet and can be a very opportunistic species with a diet that depends on its environment and the type of vegetation found in its habitat. This new information demonstrates how little is currently known about the diet of birds, even the most common and most widely distributed species, such as Cnemotriccus fuscatus in the Pantanal of Mato Grosso, Brazil.

\section{Acknowledgments}

The authors would like to thank Cemave for providing birds rings, CAPES, NEPA/UFMT, CPP, INAU, PELD and MCT for logistical support and Paul Lynch for the English review.

\section{References}

ALHO, CJR., 2008. Biodiversity of the Pantanal: response to seasonal flooding regime and to environmental degradation. Brazilian Journal of Biology, vol. 68, p. 957-966.

BEAVER, DL. and BALDWIN PH., 1975. Ecological Overlap and the Problem of Competition and Sympatry in the Western and Hammond's Flycatchers. The Condor, vol. 77, p. 1-13.

Comitê Brasileiro de Registros Ornitológicos - CBRO, 2011. Listas das aves do Brasil. Available from: http://www.cbro.org.br. Access in: 12 Aug. 2011.

Centro Nacional de Pesquisas para Conservação das Aves silvestres - CEMAVE, 1994. Manual de Anilhamento de Aves Silvestres. Brasília: CEMAVE. $146 \mathrm{p}$.

CHARNOV, E. and KREBS JR., 1974. On Clutch size and fitness. Íbis, vol. 116, p. 217-219.

COLWELL, RK. and FUTUYMA DJ., 1971. On the measurement of niche breadth and overlap. Ecology, vol. 52, p. $567-576$.

COSTA, MdeF., 1999. História de um país inexistente: o Pantanal entre os séculos XVI e XVIII. São Paulo: Estação Liberdade; Kosmos. $277 \mathrm{p}$.

DURÃES, R. and MARINI, MÂ., 2003. An evaluation of the use of tartar emetic in the study of bird diets in the Atlantic Forest of southeastern Brazil. Journal of Field Ornithology, vol. 74, p. 270-280.

DURÃES, R. and MARINI, MÂ., 2005. A quantitative assessment of bird diets in the Brazilian atlantic forest, with recommendations for future diet studies. Ornitologia Neotropical, vol. 16, p. 65-83.

FERREIRA, A., 2001. Artropodofauna obtida em Cambarazal e em Landi coletada utilizando-se de armadilha atrativa, na região do pantanal de Poconé-MT. CUIABÁ: Universidade Federal de Mato Grosso. Monografia para obtenção do Grau de Bacharel em Ciências Biológicas.

GUEDES, RC., 2008. http://www.wikiaves.com.br/ guaracavucu (15 March 2012).
Gwannon 2012. The natural species search engine. http://www.gwannon.com/species/Cnemotriccus-fuscatus (20 March 2012)

HAMMER, O., HARPER, DAT. and RYAN, PD., 2001. PAST: Paleontological Statistic Software package for education and data analysis. Paleontologia Electronica, vol. 4, p. 9.

HARRIS, MB., ARCANGELO, C., PINTO, ECT., CAMARGO, G., RAMOS-NETO, MB. and SILVA, SM., 2005. Estimativas de perda da área natural da bacia do Alto Paraguai e Pantanal Brasileiro. Campo Grande: Conservação Internacional. Relatório técnico não publicado.

HURTUBIA, J., 1973. Trophic diversity measurement in sympatric predatory species. Ecology, vol. 54, p. 885-890.

LOPES, LE., FERNANDES, AM. and MARINI, MÂ., 2005. Diet of some Atlantic Forest Birds. Ararajuba, vol. 13, p. $95-103$

MACARTHUR, R. and LEVINS, R., 1967. The Limiting Similarity, Convergence, and Divergence of Coexisting Species. The American Naturalist, vol. 101, p. 377-385.

MARQUES, MI., SOUSA, WO., SANTOS, GB., BATTIROLA, LD. and ANJOS, KC., 2010. Fauna de Artropodes de solo. In FERNANDES, IM., SIGNOR, C. and PENHA, J. (Eds.) Biodiversidade no Pantanal de Poconé. Cuiabá: Centro de Pesquisa do Pantanal (CPP). p. 73-102.

MURPHY, EC. and HAUKIOJA, E., 1986. Clutch size in nidicolous birds. Current Ornitology, vol. 4, p. 141-180.

NASCIMENTO, MT. and NUNES DA CUNHA, C., 1989. Estrutura e composição florística de um Cambarazal no Pantanal de Poconé - MT. Acta Botânica Brasileira, vol. 3, p. 3-23.

NUNES DA CUNHA, C. and JUNK, WJ., 2001. Distribution of wood plant communities along the flood gradient in the Pantanal of Poconé, Mato Grosso, Brazil. International Journal of Ecology and Environmental Science, vol. 27, p. 63-70.

-, 2009. A preliminary classification of habitats of the Pantanal of Mato Grosso and Mato Grosso do Sul, and its relation to national and international wetland classification systems. In JUNK, WJ. (Ed.). The Pantanal: Ecology, biodiversity and sustainable management of a large neotropical seasonal wetland. Sofia: Pensoft Publishers. p. 127-141.

NUR, N., 1990. The Cost of reproduction in birds evaluating the evidence from manipulative and non-manipulative studies. In BLONDEL, J., GOSLER, A., LEBRETON, JD. and MCCLERRY, R. (Eds.). Population biology of Passerine birds. An integrated approach. Berlin: Springer Verlage. p. 281-296.

PADOVANI, CR., CRUZ, MLL. and PADOVANI, SLAG., 2004. Desmatamento do Pantanal Brasileiro para o ano de 2000. In proceedings of the IV Simpósio sobre Recursos Naturais e Sócio-econômicos do Pantanal. Available from: $\quad$ http://www.cpap.embrapa.br/agencia/ desmatamento/desmatamento.htm. Access in: 24 Nov. 2005.

PIACENTINI, VDEQ., GHIZONI-JR., IR., AZEVEDO, MAG. and KIRWAN, GM., 2006. Sobre a distribuição de aves em Santa Catarina, Brasil, parte I: registros relevantes para o estado ou inéditos para a Ilha de Santa Catarina. Cotinga, vol. 26, p. 25-31.

PIELOU, EC., 1975. Ecological diversity. New York: John Wiley and Sons.

PINHEIRO, RT. and DORNAS, T., 2009. Distribuição e conservação das aves na região do Cantão, Tocantins: ecótono Amazônia/Cerrado. Biota Neotropica, vol. 9, p. 187205. 
PINHO, JB. and MARINI ÂM., 2011. Using birds to set conservation priorities for Pantanal wetland forests, Brazil. Bird Conservation International, vol. 22, p. 1-15.

PINTO, OMO., 1944. Catálogo das aves do Brasil: 2.a parte São Paulo: Publicação Departamento de Zoologia. p. 1700

POULIN, B., LEFEBVRE, G. and MCNEIL, R., 1992. Tropical avian phenology in Relation to abundance and exploitation of food resources. Ecology, vol. 73, p. 2295-2309.

-, 1994. Characteristics of feeding guilds and variation in diets of bird species of three adjacent tropical sites. Biotropica, vol. 26, p. 187-197.

RIDGELY, RS. and TUDOR, G., 2009. Field Guide to the songbirds of South America, The Passerines. Austin: University of Texas Press. 750 p.

ROTENBERRY, JT., 1980. Dietary Relationships Among Shrubsteppe Passerine Birds: Competition or Opportunism in a variable environment? Ecological Monographs, vol. 50 , p. $93-110$
SHERRY, TW., 1984. Comparative dietary ecology of sympatric, insectivorous Neotropical flycatchers (Tyrannidae). Ecological Monographs. vol. 54, p. 313-338.

SIGNOR, CA. and PINHO, JB., 2011. Spatial diversity patterns of birds in a vegetation mosaic of the Pantanal, Mato Grosso, Brazil. Zoologia, vol. 28, p. 725-738.

SOUTO, GHO., 2010. Ecologia alimentar de aves insetivoras de um fragmento de mata decídua do extremo norte da Mata Atlântica. Natal: Universidade Federal do Rio Grande do Norte. Dissertação de mestrado apresentada para o Programa de Pós graduação em Ciências Biológicas.

STOUFFER, PC. and BIERREGAARD, RO., 1995. Use of Amazonia Forest fragments by understory insectivorous birds. Ecology, vol. 76, p. 2429-2445.

VASCONCELOS, MF. and NETO, SDA., 2007. Padrões de distribuição e Conservação da avifauna na região central da Cadeia do Espinhaço e áreas adjacentes, Minas Gerais , Brasil. Cotinga, vol. 28, p. 27-44.

YABE, RS., MARQUES, EJE. and MARINI, MÂ., 2010. Movements of birds among natural vegetation patches in the Pantanal, Brazil. Bird Conservation International, vol. 20, p. 400-409. 